\title{
Fruit color preference by birds and applications to ecological restoration
}

\author{
B. L. Gagettia, ${ }^{a,}$, A. J. Piratelli ${ }^{b *}$ and F. C. M. Piña-Rodrigues ${ }^{b}$ \\ ${ }^{a}$ Laboratório de Ecologia e Conservação, Programa de Pós-graduação em Conservação de Fauna, \\ Universidade Federal de São Carlos - UFSCar, Rodovia João Leme dos Santos, Km 110, \\ Itinga, CEP 18052-780, Sorocaba, SP, Brazil

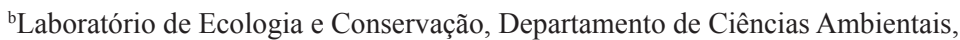 \\ Universidade Federal de São Carlos - UFSCar, Rodovia João Leme dos Santos, Km 110, \\ Itinga, CEP 18052-780, Sorocaba, SP, Brazil \\ *e-mail: piratelli@ufscar.br
}

Received: March 26, 2015 - Accepted: October 1, 2015 - Distributed: November 30, 2016

(With 3 figures)

\begin{abstract}
Ecological restoration aims to retrieve not only the structure but also the functionality of ecosystems. Frugivorous birds may play an important role in this process due to their efficiency in seed dispersal. Color perception in these animals is highly developed, and then the colors of fleshy fruits may provide important clues for choosing plant species for restoration plans. This study aims to integrate bird color preferences and restoration of degraded areas, with an objective to evaluate the potential attractiveness to birds by colored fruits. We carried out an experiment with 384 artificial fruits made of edible modeling clay with the following colors: black, blue, green and red, with 96 fruits of each color in six sites, including four restored areas and two second-growth forest fragments. We also tested the possible effect of light intensity on fruit consumption by color. A total of $120(38.6 \%)$ were assumed to be consumed by birds, and the fruit consumption varied in response to the location and light incidence. Consumption of black and blue fruits was not related to site by chance. Notwithstanding, red and black fruits were consumed significantly more than any other colors, emphasizing bird preference to these colors, regardless of location. Enrichment with shade tolerant shrubs or forest species with black or red fruits may be an alternative way to manage established restorations. In recently established or new restorations, one may introduce pioneer shrubs or short-lived forest species which have blue fruits, but also those having black or red ones.
\end{abstract}

Keywords: artificial fruits, Atlantic Forest, frugivory, ecological succession, color perception.

\section{Preferência de cor de frutos por aves e aplicações à restauração ecológica}

\section{Resumo}

A restauração ecológica tem a finalidade de recuperar não apenas a estrutura, mas também a funcionalidade dos ecossistemas, e as aves frugívoras podem desempenhar um papel importante neste processo devido à sua eficiência na dispersão de sementes. Como a percepção da cor nestes animais é altamente desenvolvida, a cor dos frutos carnosos pode ser uma característica importante na escolha de espécies de plantas para os reflorestamentos. Este estudo tem como foco integrar a preferência de cor de frutos por aves e a recuperação de áreas degradadas, objetivando determinar a atratividade potencial de aves por frutos de cores diferentes. Foi realizado um experimento com 384 frutos artificiais feitos com massa de modelar comestível nas cores preta, azul, verde e vermelha, com um total de 96 frutos em cada cor em seis locais, incluindo quatro áreas restauradas e dois fragmentos de floresta secundária. Também foi testado o possível efeito da intensidade de luz sobre o consumo de frutos conforme as cores. Um total de $120(38,6 \%)$ frutos foi considerado consumido pelas aves, e o consumo variou em resposta aos locais e incidência de luz. O consumo de frutos pretos e azuis foi significativamente relacionado com o local. Os frutos vermelhos e pretos foram significativamente mais consumidos do que as outras cores, enfatizando a preferência aves por essas cores, independentemente do local. $\mathrm{O}$ enriquecimento com espécies tolerantes à sombra com frutos pretos ou vermelhos pode ser uma alternativa para manejo de restaurações já estabelecidos; enquanto nos recentemente criados podem ser introduzidas espécies pioneiras ou florestais de vida curta com frutos azuis, pretos ou vermelhos.

Palavras-chave: frutos artificiais, Mata Atlântica, frugivoria, sucessão ecológica, percepção de cores. 


\section{Introduction}

Humans have converted large areas of tropical, native vegetation into landscapes of mixed crops, pastureland, and frequently isolated remnants of native vegetation (Laurance and Bierregaard, 1997; Steffen et al., 2011). Such mosaics have led to an impoverishment in tropical biodiversity (Fahrig, 2003) and losses of functionality and ecosystem services, as pest and diseases control and plant recruitment (Classen et al., 2014; Gray and Lewis, 2014; Moleón et al., 2014).

Ecological restoration aims to assist the recovery of a degraded ecosystem (SER, 2004) within a functional perspective, allowing goals of increasing ecosystem sustainability and their services (Suding, 2011; Stanturf et al., 2014). These processes may be accelerated by enhancing plant-animal networks (Piña-Rodrigues et al., 2009). Plants and animals have multiple relationship levels, such as predation, pollination and seed dispersal (Menz et al., 2011; Nuismer et al., 2013), and these interactions represent opportunities to establish a continuous regeneration, since animals may be considered as natural "sowers" and "planters" (Cole et al., 2010; McConkey et al., 2012). Likewise, the maintenance of species diversity is considered an important regulating ecosystem service (Isbell et al., 2011).

Zoochory is the most common way of seed dispersal in tropical forests (Barcelos et al., 2012; Gonçalves et al., 2015 and references therein). Animal-dispersed fruits are usually fleshy berries or drupe, or dehiscent capsules that expose the seeds involved with an aril, which contains sources of carbohydrates and lipids (Fleming and John Kress, 2011).

Birds are the main frugivorous in the Neotropics and are efficient seed dispersers because they are very mobile and have high metabolism that requires constant energy consumption (Whelan et al., 2008; Gonçalves et al., 2015). They also show color sensitivity (Hart, 2001) and well developed brain and vision, which allow for learning (Martin, 1993). Color preferences and fidelity have been reported in previous studies (e.g. Puckey et al., 1996; Whitney, 2005); however, this may be transient and strongly depend upon the environment (Schmidt et al., 2004). Then, we may predict a non-random variation in fruit choice, based not only by colors but also due to the contrast that each color has in different background, which varies in areas having different luminosities.

Many frugivorous birds are able to use human-modified environments (such as crop fields and forest edges) and/or move across open areas and forest fragments (Gomes et al., 2008), thus increasing seed dispersal along their route and acting as "mobile links" (Lundberg and Moberg, 2003; Piña-Rodrigues et al., 2009). In this scenario, ecological restoration of degraded land also has the function of making this area more permeable and "bird-friendly", reestablishing links among isolated forest remnants and allowing gene flow and increasing biological and functional diversity (Cavallero et al., 2012). Thus, if appropriate species are used in a given restored area, forest enrichment with attractive species may increase functional processes such as seed dispersal.
Therefore, the aim of this study was to integrate fruit color preference by birds and restoration of degraded areas, in order to evaluate the potential attractiveness of birds by colored fruits in different sites. Our premise is that birds are generally attracted and consume fruits that are more conspicuous, considering that the choice of fruit also depends on the environment and light intensities. We predict that in recently restored areas, fruits would be more detected and consumed due to the high luminosity of these open areas. Then we discuss the use of plant species whose fruits would be more attractive in each situation, which would increase seed dispersal and accelerate the process of ecological succession.

\section{Material and Methods}

\subsection{Study area}

We performed fieldwork near the city of Itu in the state of São Paulo, Southeastern Brazil (see Figure 1a) in a 526-ha area (lat $23^{\circ} 14^{\prime} 15.18^{\prime \prime S}$; long 4724'3.29'W). The regional predominant physiognomy is the seasonal semidecidual Atlantic Forest with a transition to Cerrado, which is characterized by its climatic seasonality (Veloso et al., 1991). The climate is temperate humid with dry winters and hot summers. The average rainfall is $160 \mathrm{~mm}$ for the rainy period and 56mm for dry season (Cepagri, 2015).

The area is a 400 ha of abandoned pasture and croplands inserted in a restoration program (Martins, 2011). We defined three habitat-types (recent, old-restored areas, and natural fragments), where we selected six study sites: two 3-year old areas (0.91 and 1.30-ha; from now RN1 and RN2), two 6-year-old restored sites ( 0.25 and 1.20-ha; from now RO1 and RO2) and two forest fragments with 9 and 23 ha (hereinafter F1 and F2). The study sites were mainly surrounded by pastures of Urochloa decumbens L. (Poaceae) (Figure 2).

The restorations were planted in 2005 (RO1 and RO2) and 2008 (RN1 and RN2), according to the "filling and diversity" methodology (Nave and Rodrigues, 2007). Fill species include those faster grow that provide shade to the others, and the "diversity" consists of those that increase the area diversity. The local seedling nursery produces 189 native tree species, mainly from initial (pioneers and early secondary) successional stages. About $49.2 \%$ of the species are abiotically dispersed and $50.8 \%$ of the species are animal-dispersed (Appendix A). Species were randomly planted in alternating rows of pioneers and non-pioneers species, keeping $2 \times 3 \mathrm{~m}$ between rows. After three years, the dominant species were Schinus terebinthifolius Raddi, Cytharexyllum myrianthum Cham., Guazuma ulmifolia Lam., Machaerium nyctitans (Vell.) Benth, Luehea divaricata Mart. and Cedrela fissilis Vell.

\subsection{Fruit color preference}

We carried out an experiment in November 2011 with 384 artificial fruits made of odorless edible clay (Wennersten and Forsman, 2009). We made 2-cm spherical fruits, dyed in either black, blue, green or red, with 96 fruits of each 


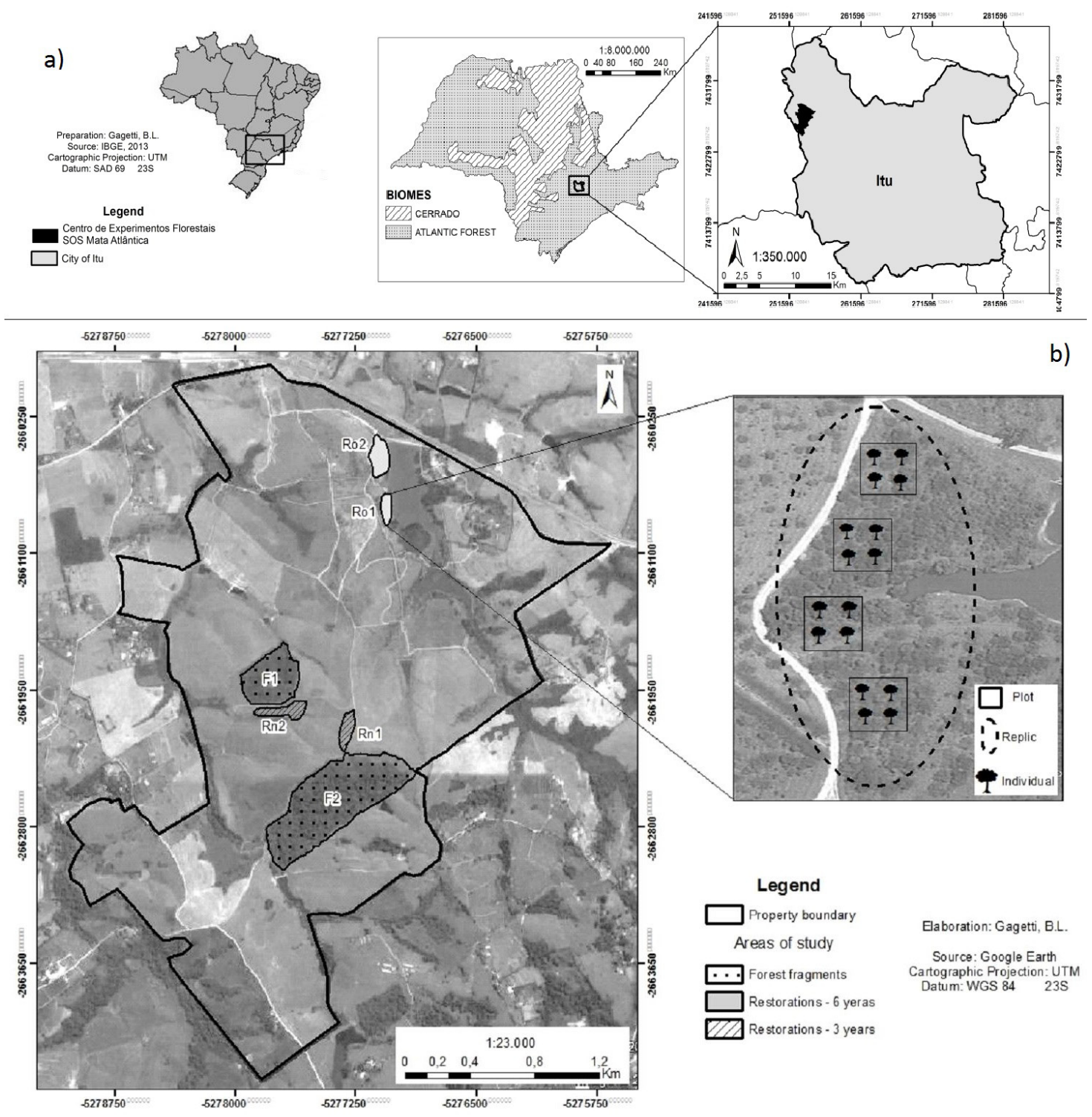

Figure 1. (a) Location of the study area in the state of São Paulo, Brazil; (b) Location of the study area and schematic illustration of the sampling design used in the experiment on the preference of fruit color. F1 and F2 = forest fragments; $\mathrm{RO} 1$ and $\mathrm{RO} 2$ = restoration of 6 year-old; RN1 and RN2 = restoration of 3-year old).

color. As the edible clay consisted of flour, butter and gelatin, we dyed the artificial fruits using food coloring.

These colors were selected because they are closer to those of naturally bird-dispersed fruits (Cazetta et al., 2009) and this technique controls variables as the number and size of fruits and position in vegetation (Alves-Costa and Lopes, 2001). In each site we set four groups of four fruits (one of each color), from now on called 'plots' in 16 trees (chosen at random), hanging in branches at about $1.5 \mathrm{~m}$ high with approximately one meter between them, totaling 64 fruits per site (see Figure 1b). We checked the experiment two times, once after 24 and again after 48 hours.
Fruits that were removed or that had beak marks were considered as "consumed" (see Figure 2). We disregard of our analysis those fruits that were dropped and/or damaged by ants and/or mammals. We did not replace either predated or bird-consumed fruits. If mammals are mainly guided by the sense of smell (Munger et al., 2009), then they would prefer fruits having odor (Barcelos et al., 2012). Furthermore, tropical fruits are thought to have a strong dichotomy of colors; fruits consumed by mammals are often orange, yellow or brown, while bird-dispersed fruits would be predominantly red or black (Willson and Whelan, 1990). Thus, this set of characteristics may 

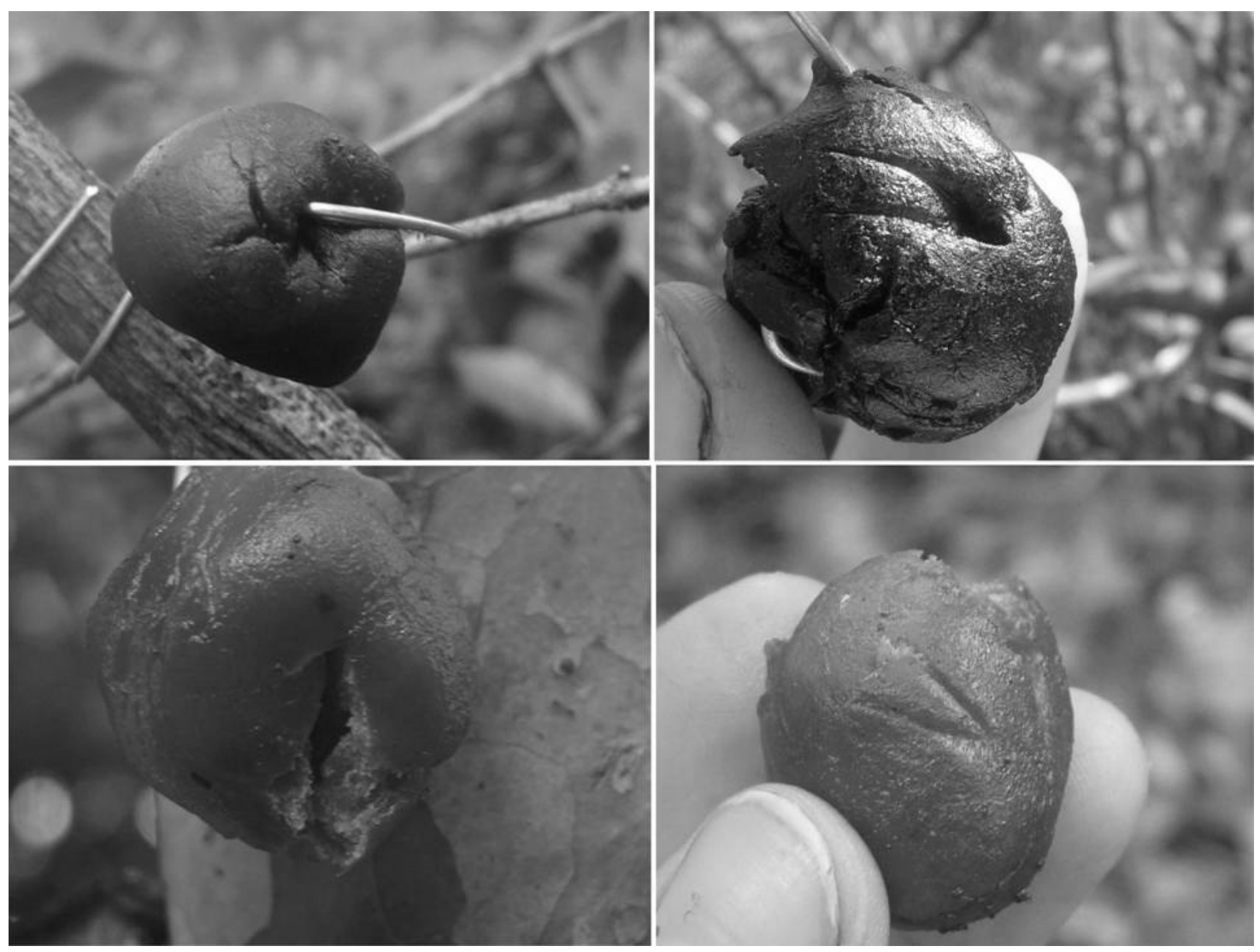

Figure 2. Examples of artificial fruits having pecking marks.

support our decision to consider the removed fruits as consumed by birds.

We also tested the possible effect of light intensity on the fruit consumption by birds, assuming that the light intensity affect fruit conspicuousness (Schmidt et al., 2004). We measured each plot in the morning, choosing individual plants and taking photographs with the lens facing upward in the same place where the fruits were hung. Next, we calculated the luminosity (\%) using the Adobe Photoshop CS5 software, following Engelbrecht and Herz (2001) with some adaptations. Each photo was converted to grayscale, dividing the image into two colors (black and white) and the percentage of white, which is equivalent to light intensity, was seen through the image histogram. In each area, we calculated the weighted average of the four plots.

\subsection{Statistical analyses}

The total fruit consumed (TFC) was calculated by adding the fruit consumed by color in the four plots at the six sites $(\mathrm{n}=24)$. As the TFC did not show normality based on the Shapiro-Wilk Test $(\mathrm{p}<0.01)$, we transformed data using log $(x+0.5)$, and $\log [(x+0.5) / 100]$ to light intensity. We tested light intensity in the six sites using analysis of variance (AOV) followed by Tukey HSD to compare means, and a box-plot to assess the light homogeneity among them.
Then, we performed a Spearman rank-correlation index using percentage of light intensity and mean of consumed fruits by plot in order to evaluate the relationship between light and color preference by birds; next, we carried out a Kruskall-Wallis One-way AOV and Dunn's all-pairwise comparisons to evaluate TFC by habitat-type.

We used a general analysis of variance (General-AOV) to check for the simultaneous effects of light incidence and fruit color consumption by site, with light as the covariate and colors as dependent variables $(n=4)$ and sites $(n=6)$ as a model statement. In order to compare means, we applied a pairwise comparison using LSD to report homogeneous sites by fruit color and T-paired for each color using the fruit consumption by plot. All statistical analyses were performed in Statistix 10.0 (Analytical Software, 2013).

\section{Results}

A total of $73(19 \%)$ of the 384 exposed fruits were found fallen $(\mathrm{n}=31)$ and/or were predated by mammals $(n=27)$ and/or ants $(n=15)$, and were not included in our analyses. From the 311 remaining fruits, 120 (38.6\% of the total) were assumed to be consumed by birds (Table 1).

The incidence of light was heterogeneous within the study area; sites F1 and RN1 were the most homogeneous in terms of the plot's light incidence, while RN2 and RO2 
had the highest heterogeneity (as shown in Table 1; see Figure 3). Across sites, only F1 was different from the others, and probably due to this, the habitat-types diverge in light intensity $(F=5.74 ; p=0.0103)$. Although new and old restorations did not differ between themselves $\left(\bar{X}_{\text {new }}=52.5 \pm 12.6 \% ; \bar{X}_{\text {old }}=40.6 \pm 15.0 \%\right)$, the new-restorations were significantly different and more open than fragments $\left(\overline{\mathrm{X}}_{\text {fragment }}=25.5 \pm 14.3 \%\right)$.
Only the general consumption of red fruits was slightly correlated $(\mathrm{r}=0.59 ; p<0.05)$ to light intensity. Despite this, when we evaluate each site, the light did not influence fruit consumption of red $\left(\mathrm{F}_{\text {red }}=0.96 ; p>0.05\right)$, probably due to the high variation of light between plots (see Figure 3). The light incidence also did not affect fruit consumption of the other colors $\left(\mathrm{F}_{\text {black }}=1.40 ; \mathrm{F}_{\text {blue }}=1.11\right.$; $\left.\mathrm{F}_{\text {green }}=1.02 ; p>0.05\right)$.

Table 1. Study sites, light intensity (\%) and total of fruit consumed by color near the city of Itu in the state of São Paulo, Brazil.

\begin{tabular}{|c|c|c|c|c|c|c|c|c|}
\hline \multirow{2}{*}{ Areas } & \multicolumn{2}{|c|}{$\begin{array}{c}\text { Light } \\
\text { intensity }(\%)\end{array}$} & \multicolumn{5}{|c|}{ Fruit color } & \multirow{2}{*}{$\begin{array}{l}\text { Total } \\
\text { TFC }\end{array}$} \\
\hline & Sites & $\begin{array}{c}\text { Habitat } \\
\text { type }\end{array}$ & Black & Blue & Green & Red & $\overline{\mathbf{X}}$ & \\
\hline F1 & $12( \pm 4.3)^{\mathrm{B}}$ & $30^{\mathrm{B}}$ & $1^{\mathrm{B}}$ & $0^{\mathrm{C}}$ & 3 & 7 & $3 \pm 1.71$ & $11^{\mathrm{BC}}$ \\
\hline $\mathrm{F} 2$ & $39( \pm 20.2)^{\mathrm{A}}$ & & $5^{\mathrm{AB}}$ & $3^{\mathrm{B}}$ & 5 & 6 & $5 \pm 2.21$ & $19^{\mathrm{AB}}$ \\
\hline RO1 & $44( \pm 30.0)^{\mathrm{A}}$ & $42^{\mathrm{AB}}$ & $6^{\mathrm{A}}$ & $8^{\mathrm{A}}$ & 1 & 6 & $5 \pm 2.99$ & $21^{\mathrm{ABC}}$ \\
\hline $\mathrm{RO} 2$ & $37( \pm 14.4)^{\mathrm{A}}$ & & $6^{\mathrm{AB}}$ & $4^{\mathrm{B}}$ & 6 & 5 & $5 \pm 0.96$ & $21^{\mathrm{BC}}$ \\
\hline RN1 & $54( \pm 8.8)^{\mathrm{A}}$ & $48^{\mathrm{A}}$ & $12^{\mathrm{A}}$ & $10^{\mathrm{A}}$ & 10 & 13 & $11 \pm 2.7$ & $45^{\mathrm{A}}$ \\
\hline RN2 & $51( \pm 48)^{\mathrm{A}}$ & & $1^{\mathrm{B}}$ & $0^{\mathrm{C}}$ & 1 & 1 & $1 \pm 0.95$ & $3^{c}$ \\
\hline Total (TFC) & - & - & $31^{\mathrm{ab}}$ & $25^{\mathrm{b}}$ & $26^{\mathrm{b}}$ & $38^{\mathrm{a}}$ & & 120 \\
\hline$F_{\text {value }}$ & 5.96 & 0.11 & 3.50 & 11.51 & 2.19 & 2.53 & & 2.85 \\
\hline$P$ & 0.0020 & $Z=2.34$ & 0.0219 & 0.000 & 0.1010 & 0.066 & & 0.0455 \\
\hline
\end{tabular}

${ }^{a}$ Values are replicate plot means $( \pm \mathrm{SD}) n=64$ for each study site. Means with the same capital letter (A, B, C) are not significantly different across study sites (mean differentiation using LSD, $\alpha=0.05$, and habitat-types by Dunn's $z$ value). Means with the same lower case letter $(\mathrm{a}, \mathrm{b})$ are not significantly different across fruit colors (mean differentiation using T-paired $\alpha=0.05$ ). $\mathrm{F} 1$ and F2 = forest fragments; RO1 and RO2 = restoration of 6 years-old; RN1 and RN2 = restoration of 3-years old. TFC=total of fruit consumption.

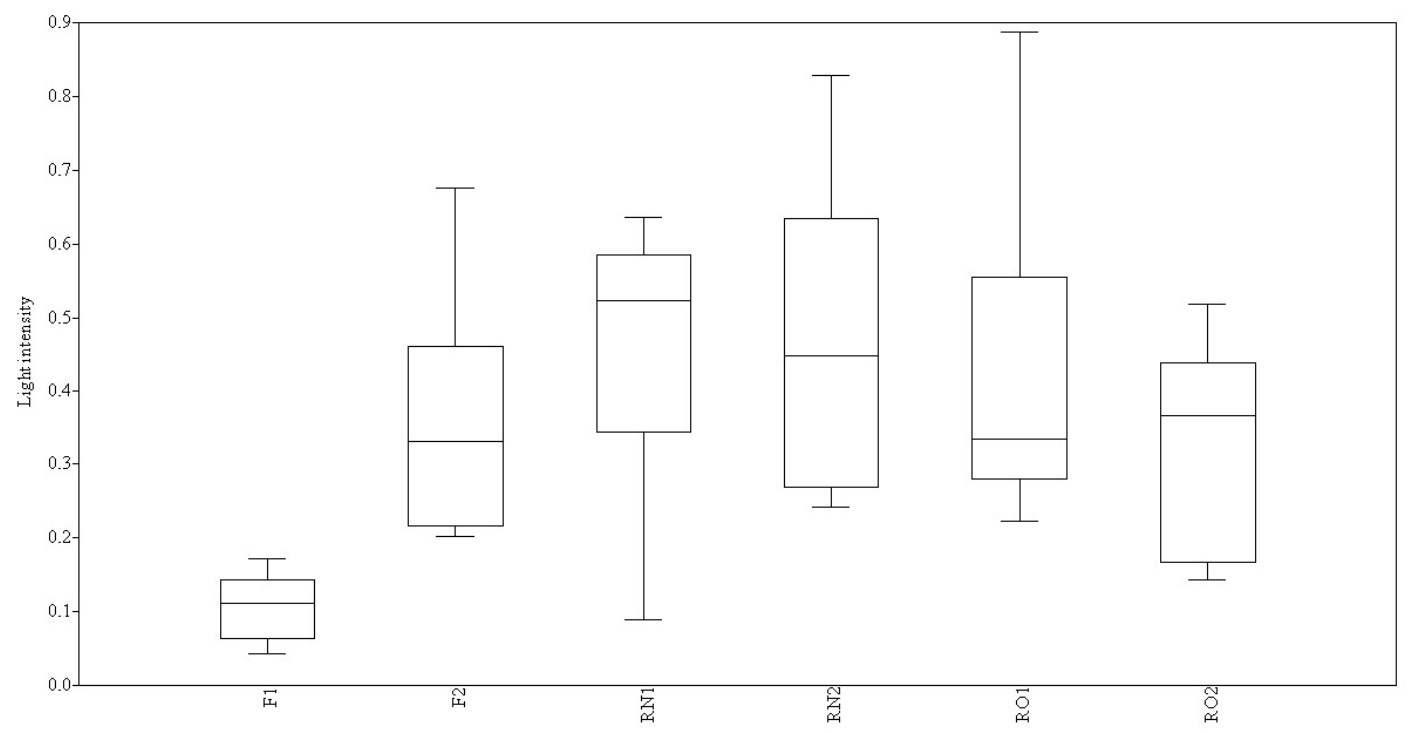

Figure 3. Box plot - median and quartiles (quartile method interpolation) - for light intensity in six studied sites in the state of São Paulo, Brazil. F1 and F2 = forest fragments; RN1 and RN2 = restoration of 3-years old, and RO1 and RO2 = restoration of 6 years-old. 
The habitat-types did not affect the overall consumption of fruits (TFC) $(\mathrm{F}=0.11 ; p>0.05)$; and the variation within each site was higher than between them $(\mathrm{F}=1.08 ; p<0.05)$, suggesting that sites, not habitat-types, influenced fruit consumption. Indeed, fruit consumption was significantly higher in RN1 and differed across sites (Table 1). The two newer restorations (RN1 and RN2) differed in relation to fruit consumption, which did not occur when comparing the older restorations ( $\mathrm{RO} 1$ and $\mathrm{RO} 2$ ).

The consumption of black and blue fruits was related significantly to sites, but not for red $(\mathrm{F}=2.53 ; p>0.05)$ or green $(\mathrm{F}=2.19 ; p>0.05)$. Notwithstanding, the red fruits were consumed significantly more than other colors regardless the site, with black being the only exception. However, the consumption of black and blue fruits differed between the two new-restorations and they were intensively pecked in RN1. Although black (31 fruits) and blue (25 fruits) did not differ in relation to the total amount of fruit consumed, only few black and none of the blue fruits were pecked by birds in the sites F1 and RN2.

\section{Discussion}

We found no influence of light exposition on fruit consumption by birds, even though this may affect color conspicuousness (e.g. Cazetta et al., 2009). This is probably due to the light heterogeneity within each site. This heterogeneity in the recovered sites is probably a consequence of the filling and diversity methodology, which mix species with wider and sparser canopies used to foster sucessional processes (Rodrigues et al., 2009).

Species composition and arrangement affected light heterogeneity only for new restorations, that also differed in fruit consumption. This suggests that fruit consumption by birds may be more affected by sites mainly in their early stages. Confirming that, in the forest fragments fruit consumption was not affected, and the spatial heterogeneity of light incidence may be explained both by the expected stratification in understories of semidecidual forests, and by their relatively small size (see study area) and the consequent degradation process.

In general, we observed a higher consumption of blue and black fruits in the restored areas than in the fragments, and the consumption of red and green were site-independent (Table 1). Color conspicuousness may be relative and influenced by factors such as the type of environment and luminosity (Arruda et al., 2008), and the contrast between the fruit and the foliage in the background (Schmidt et al., 2004; Cazetta et al., 2009). Thus, different colors may be more or be less conspicuous depending on the conditions of a given area. Galetti et al. (2003) observed a strong trend towards a higher consumption of red and black fruits in relation to white ones in large fragments, whereas this difference was less pronounced in smaller and more fragmented areas.

Our study is consistent with the premise that red and black fruit displays are an evolutionary trait associated with the reported preference of tropical birds to these colors (e.g. Wheelwright and Janson, 1985). For black and blue fruits there was a potential site preference by birds to these fruit colors, independent of habitat type.

In our restored areas few species had black $(\mathrm{n}=22 ; \sim 11 \%)$ or red $(\mathrm{n}=22 ; \sim 11 \%)$ fruits, while none were blue, and about $93(\sim 49 \%)$ species were unattractive to birds (mainly wind-dispersed) (see Appendix A), which are diverging to tropical forests, where red and black fruits represent $50 \sim 70 \%$ of all fleshy fruits (Wheelwright and Janson, 1985).

In restored areas, animal seed dispersion is an ecosystem ecological functionality that is expected to be recovered and managed (SER, 2002). For attracting birds, an appropriate species selection and management of the area is required. Adaptive management is a challenge for restorers as it depends on research and science as key elements for restoration decisions (Failing et al., 2013), and interference in a restoration process is necessary to establish objectives and to adjust future management actions (LoSchiavo et al., 2013).

In our study, new restored sites were potentially more attractive to birds than fragments, especially for blue and black fruits, suggesting that plant species selection needs to consider these fruit colors. The re-establishment of ecosystem functionality and services is one of the most important goals in restoration ecology and often exhibits divergent and unpredictable pathways (Chazdon, 2008). Enrichment with shade tolerant shrubs or forest species with black and/or red fruits may be an alternative way to manage established restorations. On the other hand, in recently established or new restorations, the introduction of pioneer shrubs or short-lived forest species having blue fruits would be more appropriate, but also those having black or red ones might be considered.

Adaptive practices may be used to manage forest restoration, by selecting pioneers with blue (e.g. Psychotria suterella Müll. Arg. and Miconia affinis DC) or black (e.g. Myrsine coriacea (Sw.) R.Br. ex Roem. \& Schult. and Dendropanax cuneatus (DC.) Decne. \& Planch.) fruits and secondary or climax species with more conspicuous fruits such as red (e.g. Cabralea canjerana (Vell.) Mart. and Cordia ecalyculata Vell.) or black (e.g. Cupania vernalis Cambess. and Nectandra megapotamica (Spreng.) Mez).

Our results suggest that fruit color should be taken into account when selecting the species to be used in reforestation programs, whether planting or enrichment. This could speed up the process of ecological succession and optimize the recovery of degraded areas.

\section{Acknowledgements}

We thank Aretha Medina and all the staff of Centro de Experimentos Florestais de Itu/SOS Mata Atlântica, for their support during the fieldwork. We also thank Mariana de Castro, Marina Maximiano and Leandro Moraes for their help in the field, Fiorella F. M. Capelo for suggestions of some species having blue fruits and two anonymous referees for their revisions, which have significantly improved this manuscript. 


\section{References}

ALVES-COSTA, P. and LOPES, A.V., 2001. Using artificial fruits to evaluate fruit selection by birds in the field. Biotropica, vol. 33, no. 4, pp. 713-717. http://dx.doi.org/10.1111/j.1744-7429.2001. tb00230.x.

ANALYTICAL SOFTWARE, 2013. [viewed 2 January 2015]. Statistix 8.0 [software]. Available from: http://www.statistix. $\mathrm{com} /$ free-trial/

ARRUDA, R.D., RODRIGUES, J. and IZZO, T.J., 2008. Rapid assessment of fruit-color selection by birds using artificial fruits at local scale in Central Amazonia. Acta Amazonica, vol. 38, no. 2, pp. 291-296. http://dx.doi.org/10.1590/S0044-59672008000200011.

BARCELOS, A.O., PERÔNICO, C.P. and EUTRÓPIO, F.J., 2012. Color and odor of artificial fruit used to signal potential dispersers in the Atlantic forest in Brazil. Revista de Biologia Tropical, vol. 60, no. 2, pp. 925-931. PMid:23894956.

CAVAlLERO, L., RAFFAELE, E. and AIZEN, M.A., 2012. Birds as mediators of passive restoration during early post-fire recovery. Biological Conservation, vol. 158, pp. 342-350. http:// dx.doi.org/10.1016/j.biocon.2012.10.004.

CAZETTA, E., SCHAEFER, H.M. and GALETTI, M., 2009. Why are fruits colorful? The relative importance of achromatic and chromatic contrasts for detection by birds. Evolutionary Ecology, vol. 23, no. 2, pp. 233-244. http://dx.doi.org/10.1007/ s10682-007-9217-1.

CENTRO DE PESQUISAS METEOROLÓGICAS E CLIMÁTICAS APLICADAS À AGRICULTURA - CEPAGRI, 2015 [viewed 20 February 2015]. Clima dos Municipios Paulistas [online]. Available from: http://www.cepagri.unicamp.br/outras-informacoes/ clima-dos-municipios-paulistas.html

CHAZDON, R.L., 2008. Beyond deforestation: restoring forests and ecosystem services on degraded lands. Science, vol. 320, no. 5882, pp. 1458-1460. http://dx.doi.org/10.1126/science.1155365. PMid:18556551.

CLASSEN, A., PETERS, M.K., FERGER, S.W., HELBIGBONITZ, M., SCHMACK, J.M., MAASSEN, G., SCHLEUNING, M., KALKO, E.K.V., BÖHNING-GAESE, K. and STEFFANDEWENTER, I., 2014. Complementary ecosystem services provided by pest predators and pollinators increase quantity and quality of coffee yields. Proceedings. Biological Sciences, vol. 281, no. 1779, pp. 1-7. http://dx.doi.org/10.1098/rspb.2013.3148. PMid:24500173

COLE, R.J., HOLL, K.D. and ZAHAWI, R.A., 2010. Seed rain under tree islands planted to restore degraded lands in a tropical agricultural landscape. Ecological Applications, vol. 20, no. 5, pp. 1255-1269. http://dx.doi.org/10.1890/09-0714.1. PMid:20666248.

ENGELBRECHT, B.M. and HERZ, H.M., 2001. Evaluation of different methods to estimate understorey light conditions in tropical forests. Journal of Tropical Ecology, vol. 17, no. 2, pp. 207-224. http://dx.doi.org/10.1017/S0266467401001146.

FAHRIG, L., 2003. Effects of habitat fragmentation on biodiversity. Annual Review of Ecology Evolution and Systematics, vol. 34, no. 1, pp. 487-515. http://dx.doi.org/10.1146/annurev. ecolsys.34.011802.132419.

FAILING, L., GREGORY, R. and HIGGINS, P., 2013. Science, uncertainty, and values in ecological restoration: a case study in structured decision-making and adaptive management.
Restoration Ecology, vol. 21, no. 4, pp. 422-430. http://dx.doi. org/10.1111/j.1526-100X.2012.00919.x.

FLEMING, T.H. and JOHN KRESS, W., 2011. A brief history of fruit and frugivores. Acta Oecologica, vol. 37, no. 6, pp. 521-530. http://dx.doi.org/10.1016/j.actao.2011.01.016.

GALETTI, M., ALVES-COSTA, C.P. and CAZETTA, E., 2003. Effects of forest fragmentation, anthropogenic edges and fruit colour on the consumption of ornithocoric fruits. Biological Conservation, vol. 111, no. 2, pp. 269-273. http://dx.doi.org/10.1016/ S0006-3207(02)00299-9.

GOMES, L.G.L., OOSTRA, V., NIJMAN, V., CLEEF, A.M. and KAPPELLE, M., 2008. Tolerance of frugivorous birds to habitat disturbance in a tropical cloud forest. Biological Conservation, vol. 141 , no. 3 , pp. $860-871$. http://dx.doi.org/10.1016/j. biocon.2008.01.007.

GONÇALVES, V.F., SILVA, A.M., BAESSE, C.Q. and MELO, C., 2015. Frugivory and potential of birds as dispersers of Siparuna guianensis. Brazilian Journal of Biology $=$ Revista Brasileira de Biologia, vol. 75, no. 2, pp. 300-304. http://dx.doi. org/10.1590/1519-6984.11413. PMid:26132011.

GRAY, C.L. and LEWIS, O.T., 2014. Do riparian forest fragments provide ecosystem services or disservices in surrounding oil palm plantations? Basic and Applied Ecology, vol. 15, no. 8, pp. 693700. http://dx.doi.org/10.1016/j.baae.2014.09.009.

HART, N.S., 2001. The visual ecology of avian photoreceptors. Progress in Retinal and Eye Research, vol. 20, no. 5, pp. 675-703. http://dx.doi.org/10.1016/S1350-9462(01)00009-X. PMid:11470455.

ISBELL, F., CALCAGNO, V., HECTOR, A., CONNOLLY, J., HARPOLE, W.S., REICH, P.B., SCHERER-LORENZEN, M., SCHMID, B., TILMAN, D., VAN RUIJVEN, J., WEIGELT, A., WILSEY, B.J., ZAVALETA, E.S. and LOREAU, M., 2011. High plant diversity is needed to maintain ecosystem services. Nature, vol. 477, no. 7363, pp. 199-202. http://dx.doi.org/10.1038/ nature10282. PMid:21832994.

LAURANCE, W.F. and BIERREGAARD, R.O., 1997. Tropical forest remnants: ecology, management and conservation of fragmented communities. Chicago: University of Chicago Press. 632 p.

LOSCHIAVO, A.J., BEST, R.G., BURNS, R.E., GRAY, S., HARWELL, M.C., HINES, E.B., MCLEAN, A.R., ST. CLAIR, T., TRAXLER, S. and VEARIL, J.W., 2013. Lessons learned from the first decade of adaptive management in comprehensive Everglades restoration. Ecology and Society, vol. 18, no. 4, pp. 70. http://dx.doi.org/10.5751/ES-06065-180470.

LUNDBERG, J. and MOBERG, F., 2003. Mobile link organisms and ecosystem functioning: implications for ecosystem resilience and management. Ecosystems, vol. 6, no. 1, pp. 87-98. http:// dx.doi.org/10.1007/s10021-002-0150-4.

MARTIN, G.R., 1993. Producing the image. In: H.P. ZEIGLER and H.J. BISCHOF, eds. Vision brain, and behavior in birds. Cambridge: MIT Press. p. 5-24.

MARTINS, A.F., 2011. Controle de gramíneas exóticas invasoras em área de restauração ecológica com plantio total, Floresta Estacional Semidecidual, Itu, SP. Piracicaba: Universidade de São Paulo. 112 p. Dissertação de Mestrado em Recursos Florestais.

MCCONKEY, K.R., PRASAD, S., CORLETT, R.T., CAMPOSARCEIZ, A., BRODIE, J.F., ROGERS, H. and SANTA-MARIA, L., 2012. Seed dispersal in changing landscapes. Biological Conservation, vol. 146, no. 1, pp. 1-13. http://dx.doi.org/10.1016/j. biocon.2011.09.018. 
MENZ, M.H.M., PHILLIPS, R.D., WINFREE, R., KREMEN, C., AIZEN, M.A., JOHNSON, S.D. and DIXON, K.W., 2011. Reconnecting plants and pollinators: challenges in the restoration of pollination mutualisms. Trends in Plant Science, vol. 16, no. 1, pp. 4-12. http://dx.doi.org/10.1016/j.tplants.2010.09.006. PMid:20980193.

MOLEÓN, M., SÁNCHEZ-ZAPATA, J.A., MARGALIDA, A., CARRETE, M., OWEN-SMITH, N. and DONÁZAR, J.A., 2014. Humans and Scavengers: the evolution of interactions and ecosystem services. Bioscience, vol. 64, no. 5, pp. 394-403. http:// dx.doi.org/10.1093/biosci/biu034.

MUNGER, S.D., LEINDERS-ZUFALL, T. and ZUFALL, F., 2009. Subsystem organization of the Mammalian sense of smell. Annual Review of Physiology, vol. 71, no. 1, pp. 115-140. http://dx.doi. org/10.1146/annurev.physiol.70.113006.100608. PMid:18808328.

NAVE, A.G. and RODRIGUES, R.R., 2007. Combination of species into filling and diversity groups as forest restoration methodology. In: R.R. RODRIGUES, S.V. MARTINS and S. GANDOLFI, orgs. High diversity forest restoration in degraded areas: methods and projects in Brazil. New York: Nova Science Publishers, pp. 103-126.

NUISMER, S.L., JORDANO, P. and BASCOMPTE, J., 2013. Coevolution and the architecture of mutualistic networks. Evolution, vol. 67, no. 2, pp. 338-354. http://dx.doi.org/10.1111/j.15585646.2012.01801.x. PMid:23356608.

PIÑA-RODRIGUES, F.C.M., PIRATELLI, A.J., RUDGE, A.C., GONDIM, F.R., FREIRE, M. and CORREA, J.S., 2009. Mobile links in fragmented ecosystem: seed and birds dispersal approach towards Atlantic forest restoration and conservation. In: H. GAESE, J.C.T. ALBINO, J. WESENBERG and S. SCHLÜTER, eds. Biodiversity and land use systems in the fragmented Mata Atlântica of Rio de Janeiro. Göttingen: Cuvillier Verlag, pp. 313-360.

PUCKEY, H.L., LILL, A. and O'DOWD, D.J., 1996. Fruit color choices of captive silvereyes (Zosterops lateralis). The Condor, vol. 98, no. 4, pp. 780-790. http://dx.doi.org/10.2307/1369858.

RODRIGUES, R.R., BRANCALION, P.H.S. and ISERNHAEN, I., 2009. Pacto pela restauração da mata atlântica: referencial dos conceitos e ações de restauração florestal. São Paulo: LERF/ ESALQ. 264 p.

SÃO PAULO. Governo do Estado. Secretaria do Meio Ambiente - SMA, 2008. [viewed 20 February 2015]. Resolução SMA - 8, de 31-1-2008. Fixa a orientação para o reflorestamento heterogêneo de áreas degradadas e dá providências correlatas [online]. São Paulo: Secretaria do Meio Ambiente. Available from: http://www. cetesb.sp.gov.br/licenciamento/documentos/2008_Res_SMA_08.pdf

SCHMIDT, V., SCHAEFER, H.M. and WINKLER, H., 2004. Conspicuousness, not colour as foraging cue in plant-animal signaling. Oikos, vol. 106, no. 3, pp. 551-557. http://dx.doi. org/10.1111/j.0030-1299.2004.12769.x.

SOCIETY FOR ECOLOGICAL RESTORATION - SER, 2002. SER primer on ecological restoration. Washington: SER. $16 \mathrm{p}$.

SOCIETY FOR ECOLOGICAL RESTORATION - SER, 2004. [viewed 21 August 2015]. The SER primer on ecological restoration [online]. Washington: SER. Available from: http://www.ser.org/

STANTURF, J.A., PALIK, B.J. and DUMROESE, R.K., 2014. Contemporary forest restoration: a review emphasizing function. Forest Ecology and Management, vol. 331, pp. 292-323. http:// dx.doi.org/10.1016/j.foreco.2014.07.029.

STEFFEN, W., PERSSON, Å., DEUTSCH, L., ZALASIEWICZ, J., WILLIAMS, M., RICHARDSON, K., CRUMLEY, C., CRUTZEN, P., FOLKE, C., GORDON, L., MOLINA, M., RAMANATHAN, V., ROCKSTRÖM, J., SCHEFFER, M., SCHELLNHUBER, H.J. and SVEDIN, U., 2011. The Anthropocene: From Global Change to Planetary Stewardship. Ambio, vol. 40, no. 7, pp. 739-761. http://dx.doi.org/10.1007/s13280-011-0185-x. PMid:22338713.

SUDING, K.N., 2011. Toward an era of restoration in ecology: successes, failures, and opportunities ahead. Annual Review of Ecology Evolution and Systematics, vol. 42, no. 1, pp. 465-487. http://dx.doi.org/10.1146/annurev-ecolsys-102710-145115.

VELOSO, H.P., RANGEL-FILHO, A L.R. and LIMA, J.C.A., 1991. Classificação da vegetação brasileira adaptada a um sistema universal. Rio de Janeiro: IBGE. 124 p.

WENNERSTEN, L. and FORSMAN, A., 2009. Does color polymorphism enhance survival of prey population? Proceedings of the Royal Society B, vol. 276, no. 1803, pp. 2187-2194. http:// dx.doi.org/10.1098/rspb.2009.0252.

WHEELWRIGHT, N.T. and JANSON, C.H., 1985. Colors of fruit displays of bird-dispersed plants in two tropical forests. American Naturalist, vol. 126, no. 6, pp. 777-799. http://dx.doi. org/10.1086/284453.

WHELAN, C.J., WENNY, D.G. and MARQUIS, R.J., 2008. Ecosystem services provided by birds. Annals of the New York Academy of Sciences, vol. 1134, no. 1, pp. 25-60. http://dx.doi. org/10.1196/annals.1439.003. PMid:18566089.

WHITNEY, K.D., 2005. Linking frugivores to the dynamics of a fruit color polymorphism. American Journal of Botany, vol. 92, no. 5, pp. 859-867. http://dx.doi.org/10.3732/ajb.92.5.859. PMid:21652467.

WILLSON, M. F. and WHELAN, C.J., 1990. The evolution of fruit color in fleshy-fruited plants. American Naturalist, vol. 136, no. 6, pp. 790-809. http://dx.doi.org/10.1086/285132. 
Appendix A. Plant species available in the nursery or planted in the Centro de Experimentos Florestais, in the region of Itu, state of São Paulo, with colors of fruits/diasporas and dispersal syndrome (biotic or abiotic).

\begin{tabular}{|c|c|c|}
\hline Taxon & $\begin{array}{c}\text { Fruit/diaspore } \\
\text { color }\end{array}$ & Seed dispersal* \\
\hline Acacia caven Molina & Brown & Abiotic \\
\hline Acacia polyphylla DC. & Black/Yellow & Abiotic \\
\hline Aegiphila sellowiana Cham. & Orange & Biotic \\
\hline Albizia polyphylla E. Fourn. & Brown & Abiotic \\
\hline Allophylus edulis (A. St.-Hil., A. Juss. \& Cambess.) Hieron. ex Niederl. & Red & Biotic \\
\hline Allophylus petiolulatus Radlk. & Red & Biotic \\
\hline Aloysia virgate (Ruiz \& Pav.) Pers. & White & Abiotic \\
\hline Anadenanthera falcate (Benth.) Speg. & Brown & Abiotic \\
\hline Anadenanthera macrocarpa (Benth.) Brenan & Brown & Abiotic \\
\hline Anadenanthera peregrina (L.) Speg. & Brown & Abiotic \\
\hline Annona cacans Warm. & Green & Biotic \\
\hline Annona coriácea Mart. & Green & Biotic \\
\hline Apeiba tibourbou Aubl. & Green & Abiotic \\
\hline Aspidosperma parvifolium A.DC. & Beige & Abiotic \\
\hline Aspidosperma cylindrocarpon Müll. Arg. & Brown & Abiotic \\
\hline Aspidosperma ramiflorum Müll. Arg. & Brown & Abiotic \\
\hline Astronium graveolens Jacq. & Brown & Abiotic \\
\hline Balfourodendron riedelianum (Engl.) Engl. & Yellow & Abiotic \\
\hline Bastardiopsis densiflora (Hook. \& Arn.) Hassl. & Green & Abiotic \\
\hline Bauhinia forficata Link & Brown & Abiotic \\
\hline Byrsonima sericea DC. & Yellow & Biotic \\
\hline Cabralea canjerana (Vell.) Mart. & Red & Biotic \\
\hline Calophyllum brasiliensis Camb. & Green & Biotic \\
\hline Campomanesia eugenioides (Cambess.) D. Legrand ex L.R. Landrum & Green & Biotic \\
\hline Campomanesia neriiflora (O. Berg) Nied. & Green & Biotic \\
\hline Campomanesia xanthocarpa Mart. Ex O. Berg & Yellow & Biotic \\
\hline Capsicodendron dinisii (Schwacke) Occhioni & Red & Biotic \\
\hline Cariniana estrellensis (Raddi) Kuntze & Beige & Abiotic \\
\hline Cariniana legalis (Mart.) Kuntze & Beige & Abiotic \\
\hline Casearia gossypiosperma Briq. & Yellow/Green & Biotic \\
\hline Casearia sylvestris $\mathrm{Sw}$. & Red/Black & Biotic \\
\hline Cassia ferruginea (Schrad.) Schrader ex DC. & Brown & Abiotic \\
\hline Cassia leptophylla Vogel & Brown & Abiotic \\
\hline Cecropia hololeuca Miq. & Brown & Biotic \\
\hline Cecropia pachystachya Trécul & Green & Biotic \\
\hline Cedrela fissilis Vell. & Brown & Abiotic \\
\hline Cedrela odorata L. & Brown & Abiotic \\
\hline Ceiba speciosa (A. St.-Hil.) Ravenna & Green & Abiotic \\
\hline Centrolobium tomentosum Guillemin ex Benth. & Brown & Abiotic \\
\hline Chorisia glaziovii (Kuntze) E. Santos & Green & Abiotic \\
\hline Chorisia speciose A. St.-Hil. & Green & Abiotic \\
\hline Chrysophyllum gonocarpum (Mart. \& Eichler ex Miq.) Engl. & Yellow & Biotic \\
\hline Citharexylum mirianthum Cham. & Red & Biotic \\
\hline Citharexylum solanaceum Cham. & Orange & Biotic \\
\hline Colubrina glandulosa Perkins & Black & Biotic \\
\hline Copaifera langsdorffii Desf. & Orange/Black & Biotic \\
\hline Cordia americana (L.) Gottschling \& J.S. Mill. & Brown & Abiotic \\
\hline Cordia ecalyculata Vell. & Red & Biotic \\
\hline
\end{tabular}

Source: *Resolução SMA - 8/2008 (São Paulo, 2008). **unknown. 
Appendix 1. Continued...

\begin{tabular}{|c|c|c|}
\hline Taxon & $\begin{array}{c}\text { Fruit/diaspore } \\
\text { color }\end{array}$ & Seed dispersal* \\
\hline Cordia sellowiana Cham. & Yellow & Biotic \\
\hline Cordia superba Cham. & White & Biotic \\
\hline Cordia trichotoma (Vell.) Arráb. Ex Steud. & Green & Abiotic \\
\hline Couroupita guianensis Aubl. & Yellow & Biotic \\
\hline Coutarea hexandra (Jacq.) K. Schum. & Green & Abiotic \\
\hline Croton floribundus Spreng. & Green & Abiotic \\
\hline Croton urucurana Baill. & Green & Abiotic \\
\hline Cryptocarya aschersoniana Mez & Yellow & Biotic \\
\hline Cupania vernalis Cambess. & Black/Red & Biotic \\
\hline Curatella americana $\mathrm{L}$. & Red & Biotic \\
\hline Cyclolobium vecchi A. Samp. Ex Hoehne & Beige & Abiotic \\
\hline Dendropanax cuneatum Decne. \& Planch. & Green & Biotic \\
\hline Dictyoloma vandellianum A. Juss. & Beige & Abiotic \\
\hline Dilodendron bipinnatum Radlk. & Black & Biotic \\
\hline Diospyros inconstans Jacq. & Purple & Biotic \\
\hline Diplokeleb a floribunda N.E. Br. & Brown & Abiotic \\
\hline Enterolobium contortisiliquum (Vell.) Morong & Black & Abiotic \\
\hline Enterolobium timbouva Mart. & Black & Abiotic \\
\hline Eriotheca gracilipes (K. Schum.) A. Robyns & Green & Abiotic \\
\hline Erythrina speciosa Andrews & Brown & Abiotic \\
\hline Erythrina crista-galli L. & Brown & Abiotic \\
\hline Erythrina falcate Benth. & Brown & Abiotic \\
\hline Erythrina velutina Willd. & Green & Abiotic \\
\hline Erythroxylum deciduum A. St.-Hil. & Red & Biotic \\
\hline Erythrina verna Vell. & Brown & Abiotic \\
\hline Esenbeckia leiocarpa Engl. & Green & Abiotic \\
\hline Eugenia brasiliensis Lam. & Red/Black & Biotic \\
\hline Eugenia cerasiflora Miq. & Red & Biotic \\
\hline Eugenia candolleana DC. & Black & Biotic \\
\hline Eugenia dysenterica DC. & Yellow & Biotic \\
\hline Eugenia glazioviana (Kiaersk.) D. Legrand & Yellow & Biotic \\
\hline Eugenia involucrata DC. & Red/Black & Biotic \\
\hline Eugenia luschnathiana (O. Berg) Klotzsch ex B.D. Jacks. & Yellow & Biotic \\
\hline Eugenia pyriformis Cambess. & Yellow & Biotic \\
\hline Eugenia uniflora L. & Orange/Red & Biotic \\
\hline Ficus enormis (Mart. Ex Miq.) Mart. & Red/Purple & Biotic \\
\hline Ficus guaranitica (Chodat) & Green & Biotic \\
\hline Ficus insipida Willd. & Green & Biotic \\
\hline Ficus luschnathiana (Miq.) Miq. & Red/Purple & Biotic \\
\hline Ficus obtusifolia Kunth & Yellow/Orange & Biotic \\
\hline Gallesia integrifólia (Spreng.) Harms & Beige & Abiotic \\
\hline Garcinia gardneriana (Planch. \& Triana) Zappi & Yellow & Biotic \\
\hline Genipa Americana L. & Green/Brown & Biotic \\
\hline Gochnatia polymorpha (Less.) Cabrera & White & Abiotic \\
\hline Guapira graciliflora (Mart. Ex J.A. Schmidt) Lundell & Black & Biotic \\
\hline Guarea kunthiana A. Juss. & Brown & Biotic \\
\hline Guazuma ulmifolia Lam. & Black & Biotic \\
\hline Handroanthus chrysotrichus (Mart. ex A. DC.) Mattos & Green & Abiotic \\
\hline Handroanthus heptaphyllus (Vell.) Mattos & Brown & Abiotic \\
\hline
\end{tabular}

Source: *Resolução SMA - 8/2008 (São Paulo, 2008). **unknown. 
Appendix 1. Continued...

\begin{tabular}{|c|c|c|}
\hline Taxon & $\begin{array}{c}\text { Fruit/diaspore } \\
\text { color }\end{array}$ & Seed dispersal* \\
\hline Handroanthus impetiginosus (Mart. ex DC.) Mattos & Brown & Abiotic \\
\hline Heliocarpus popayanensis Kunth & Beige & Abiotic \\
\hline Hexachlamys edulis (O. Berg) Kausel \& D. Legrand & Yellow & Biotic \\
\hline Hymenaea courbaril L. & Green & Biotic \\
\hline Inga laurina (Sw.) Willd. & Green & Biotic \\
\hline Inga marginata Willd. & Green & Biotic \\
\hline Inga uruguensis Hook. \& Arn. & Green & Biotic \\
\hline Inga vera Willd. & Green & Biotic \\
\hline Jacaranda micranta Cham. & Black & Abiotic \\
\hline Jacaratia spinosa (Aubl.) A. DC. & Yellow & Biotic \\
\hline Lafoensia glyptocarpa Koehne & Green & Abiotic \\
\hline Lafoensia pacari A. St.-Hil. & Brown & Abiotic \\
\hline Leucochloron incuriale (Vell.) Barneby \& J.W. Grimes & Yellow & Abiotic \\
\hline Lonchocarpus campestres Mart. ex Benth. & Green & Abiotic \\
\hline Lonchocarpus cultratus (Vell.) A.M.G. Azevedo \& H.C. Lima & Green & Abiotic \\
\hline Lonchocarpus muehlbergianus Hassl. & Brown & Abiotic \\
\hline Luehea divaricata Mart. & Green & Abiotic \\
\hline Luehea grandiflora Mart. & Green & Abiotic \\
\hline Mabea fistulifera Mart. & Green & Abiotic \\
\hline Machaerium hirtum (Vell.) Stellfeld & Brown & Abiotic \\
\hline Machaerium stipitatum (DC.) Vogel & Brown & Abiotic \\
\hline Machaerium villosum Vogel & Brown & Abiotic \\
\hline Machaerium brasiliense Vogel & Green & Abiotic \\
\hline Maclura tinctoria (L.) D. Don ex Steud. & Green & Biotic \\
\hline Miconia cabucu Hoehne & Yellow & Biotic \\
\hline Mimosa bimucronata (DC.) Kuntze & Brown & Abiotic \\
\hline Mimosa scabrella Benth. & Brown & Abiotic \\
\hline Myracrodruon urundeuva Allemão & Black & Abiotic \\
\hline Myrciaria floribunda (H. West ex Willd.) O. Berg & Red & Biotic \\
\hline Myrciaria glazioviana (Kiaersk.) G.M. Barroso ex Sobral & Yellow & Biotic \\
\hline Myroxylon peruiferum L.f. & Beige & Abiotic \\
\hline Myrsine umbellata Mart. & Black & Biotic \\
\hline Nectandra megapotamica (Spreng.) Mez & Black & Biotic \\
\hline Ocotea puberula (Rich.) Nees & Black/Red & Biotic \\
\hline Ormosia arborea (Vell.) Harms & Orange/Black & Abiotic \\
\hline Parapiptadenia rígida (Benth.) Brenan & Brown & Abiotic \\
\hline Peltophorum dubium (Spreng.) Taub. & Beige & Abiotic \\
\hline Persea pyrifolia (D. Don) Spreng. & Green & Biotic \\
\hline Phytolacca dioica $\mathrm{L}$. & Yellow & Abiotic \\
\hline Piptadenia gonoacantha (Mart.) J.F. Macbr. & Green & Abiotic \\
\hline Piptocarpha axillaris (Less.) Baker & $* *$ & Abiotic \\
\hline Piptocarpha rotundifolia (Less.) Baker & $* *$ & Abiotic \\
\hline Platypodium elegans Vogel & Beige & Abiotic \\
\hline Plinia edulis (Vell.) Sobral & Yellow & Biotic \\
\hline Poecilanthe parviflora Benth. & Brown & Abiotic \\
\hline Posoqueria acutifolia Mart. & Yellow & Abiotic \\
\hline Pouteria torta (Mart.) Radlk. & Yellow & Abiotic \\
\hline Prunus sellowii Koehne & Purple & Biotic \\
\hline Psidium cattleianum Sabine & Yellow & Biotic \\
\hline
\end{tabular}

Source: *Resolução SMA - 8/2008 (São Paulo, 2008). **unknown. 
Appendix 1. Continued...

\begin{tabular}{|c|c|c|}
\hline Taxon & $\begin{array}{c}\text { Fruit/diaspore } \\
\text { color }\end{array}$ & Seed dispersal* \\
\hline Psidium guajava L. & Green/Red & Biotic \\
\hline Psidium longipetiolatum D. Legrand & Purple & Biotic \\
\hline Psidium rufum DC. & Green & Biotic \\
\hline Psychotria carthagenensis Jacq. & Red & Biotic \\
\hline Pterocarpus violaceus Vogel & Beige & Abiotic \\
\hline Pterogyne nitens Tul. & Beige & Abiotic \\
\hline Rapanea ferrugínea (Ruiz \& Pav.) Mez & Black & Biotic \\
\hline Rapanea gardneriana (A. DC.) Mez & Black & Biotic \\
\hline Rauvolfia sellowii Müll. Arg. & Black & Biotic \\
\hline Rhamnidium elaeocarpum Reissek & Red & Biotic \\
\hline Sapium glandulatum (Vell.) Pax & Red & Biotic \\
\hline Schefflera morototoni (Aubl.) Maguire, Steyerm. \& Frodin & Brown & Biotic \\
\hline Schinus molle L. & Red & Biotic \\
\hline Schinus terebinthifolius Raddi & Red & Biotic \\
\hline Schizolobium parahyba (Vell.) S.F. Blake & Beige & Abiotic \\
\hline Seguieria langsdorffii Moq. & Black & Abiotic \\
\hline Senna alata (L.) Roxb. & Black & Abiotic \\
\hline Senna macranthera (DC. ex Collad.) H.S. Irwin \& Barneby & Black & Abiotic \\
\hline Senna multijuga (Rich.) H.S. Irwin \& Barneby & Brown & Biotic \\
\hline Senna pendula (Humb. \& Bonpl. ex Willd.) H.S. Irwin \& Barneby & Green & Abiotic \\
\hline Simira sampaiona (Standl.) Steyerm. & Green & Abiotic \\
\hline Solanum erianthum D. Don & Yellow & Biotic \\
\hline Solanum granuloso-leprosum Dunal & $* *$ & Biotic \\
\hline Solanum lycocarpum A. St.-Hil. & Green/Yellow & Biotic \\
\hline Solanum pseudoquina A. St.-Hil. & Yellow & Biotic \\
\hline Sparattosperma leucanthum (Vell.) K. Schum. & Beige & Abiotic \\
\hline Strychnos brasiliensis (Spreng.) Mart. & Yellow & Biotic \\
\hline Styrax pohlii A. DC. & Black & Biotic \\
\hline Syagrus romanzoffiana (Cham.) Glassman & Yellow & Biotic \\
\hline Tabebuia avellanedae Lorentz ex Griseb. & Green & Abiotic \\
\hline Tabebuia ochracea A.H. Gentry & Green & Abiotic \\
\hline Tabebuia roseo alba (Ridl.) Sand. & Green & Abiotic \\
\hline Tabernaemontana hystrix Steud. & Red & Biotic \\
\hline Terminalia argentea Mart. & Beige & Abiotic \\
\hline Terminalia brasiliensis Spreng. & Yellow & Abiotic \\
\hline Trema micranta (L.) Blume & Red & Biotic \\
\hline Vantanea compacta (Schnizl.) Cuatrec. & Yellow & Biotic \\
\hline Vitex montevidensis Cham. & Black & Biotic \\
\hline Vochysia tucanorum Mart. & Green & Abiotic \\
\hline Xylosma glaberrima Sleumer & $* *$ & Biotic \\
\hline Zanthoxylum caribaeum Lam. & Purple & Biotic \\
\hline Zanthoxylum rhoifolium Lam. & Purple & Biotic \\
\hline Zeyheria tuberculosa (Vell.) Bureau ex Verl. & Brown & Abiotic \\
\hline
\end{tabular}

Source: *Resolução SMA - 8/2008 (São Paulo, 2008). **unknown. 